DOI 10.15290/cnisk.2020.01.08.05

JOLANTA CHWASTYK-KOWALCZYK

https://orcid.org/0000-0002-3463-6432

Uniwersytet Jana Kochanowskiego w Kielcach

\title{
Ikona polskiego dziennikarstwa emigracyjnego z Londynu - Krystyna Cywińska ${ }^{1}$
}

\section{Streszczenie}

Artykuł prezentuje ostatnią dekadę dorobku publicystycznego Krystyny Cywińskiej, drukowanego na łamach londyńskiego „Nowego Czasu” w latach 2007-2017. Jest znaną dziennikarką działająca w Londynie od 1947 r. Doświadczenie zawodowe zdobywała w Radiu Wolna Europa, BBC, londyńskim „Dzienniku Polskim i Dzienniku Żołnierza” oraz jego sobotnim wydaniu „Tydzień Polski”. Przez 50 lat uprawiania dziennikarstwa wypracowała swój własny publicystyczny styl komentowania rzeczywistości społeczno-politycznej, najczęściej Polaków żyjących na emigracji. Ponieważ Krystyna Cywińska po przejściu w 2007 r. z londyńskiego „Dziennika Polskiego i Dziennika Żołnierza” do opiniotwórczego „Nowego Czasu” - tytułu stworzonego przez nową falę emigracji lat 80 . XX w. - stała się symbolem łączącym dawna emigrację $z$ młoda, uznano, że należy poszerzyć wiedzę na temat sposobu uprawiania przez nią dziennikarstwa. Analizie jakościowej zostało poddanych 119 felietonów jej autorstwa, które opublikowano w „Nowym Czasie" w latach 2007-2017.

Dziennikarka porusza następujące tematy: wyobcowanie $z$ polskości pokolenia rodaków urodzonych na Wyspach Brytyjskich, kwestie asymilacji w nowym kraju osiedlenia; namawiała Polaków, by czynnie włączyli się

1 Publikacja przygotowana/finansowana w ramach programu Ministra Nauki i Szkolnictwa Wyższego pod nazwa DIALOG w latach 2019-2021. Jest wynikiem udziału w projekcie badawczym pt. „Ośrodek badań historii kobiet”, nr 0016/DLG/2019/10. 
w życie polityczne, żyjąc na emigracji, apelowała o zachowanie czystości języka polskiego na obczyźnie, o rzetelność dziennikarska, snuła refleksje na temat świąt obchodzonych przez Polaków. $Z$ troska pochylała się nad patologia społeczna, w tym nad przemoca domowa, przestrzegała przed „dziką lustracją" w Polsce, komentowała informacje o współpracy ze Służbą Bezpieczeństwa znanych postaci życia polskiej diaspory na świecie, nie tylko w Wielkiej Brytanii. Analizowała pojęcie patriotyzmu, zmiany w Polsce po 1989 r. Interesuja ją również problemy współczesnego terroryzmu islamskich fundamentalistów, fala emigrantów napływających do Europy Zachodniej, zmiany obyczajowe po napływie emigrantów różnych narodowości do Wielkiej Brytanii, $z$ którymi kraj sobie nie radzi. Nie stroni od uwag na tematy kulturalne. Piętnuje brytyjskie czasopisma drukujacce artykuły szkalujące Polaków. Polemika jest dla niej „dusza publicystyki”.

Słowa kluczowe: Krystyna Cywińska (1925-), polska publicystyka na emigracji w XXI w., Wielka Brytania, „Nowy Czas”, 2007-2017

\title{
ICON OF POLISH JOURNALISM IN EXILE FROM LONDON - KRYSTYNA CYWIŃSKA
}

\begin{abstract}
The article presents the last decade of the journalistic output of Krystyna Cywińska, published in the pages of the London's "Nowy Czas" [New Time] in the years 2007-2017. She is a well-known journalist who have been working in London since 1947. She gained her professional experience in Radio Free Europe, BBC, London's "Dziennik Polski and Dziennik Żołnierza" and its Saturday edition, "Tydzień Polski". Having been practicing journalism for 50 years, she has developed her own style of commenting on socio-political reality, usually concerning Poles living in exile.

Keywords: Krystyna Cywińska (1925-), Polish émigré journalist in the 21st century, Great Britain, "Nowy Czas" [New Time], 2007-2017

Wkład polskich dziennikarek w budowanie przestrzeni kulturalnej rodaków na emigracji jest prawie nieznany i w głównych nurtach naukowych dotąd pomijany. Od czasów wybuchu II wojny światowej do dziś było ich kilkadziesiąt. Większość z pokolenia byłych żołnierzy Polskich Sił Zbrojnych szlify dziennikarskie zdobywała w okresie dwudziestolecia
\end{abstract}


międzywojennego, w czasie, który je ukształtował i obdarzył kręgosłupem moralnym na całe życie. Nie wszystkie na trwałe wpisały się swym warsztatem i misją w polską działalność na obczyźnie.

Każda fala emigracji zapisała się kilkoma zaledwie nazwiskami wartymi odnotowania i upamiętnienia. $Z$ pokolenia "niezłomnych” niewątpliwie sa to: Stefania Kossowska, Maria Danilewicz-Zielińska i Krystyna Cywińska. Z pokolenia emigracji lat 80. XX w., czyli „solidarnościowej”: Katarzyna Bzowska-Budd, Regina Wasiak-Taylor i Teresa Bazarnik. Najtrudniejsze do identyfikacji sa dziennikarki poakcesyjne, czyli te przybyłe do Wielkiej Brytanii po maju 2004 r. Proces dokonywania identyfikacji i selekcji trwa. Trudność polega na tym, że większość $z$ nich, aby zarobić na utrzymanie, musi podejmować inne zajęcia, często bardzo odległe od dziennikarstwa. Istotna jest problematyka, jaka podejmują w swojej publicystyce obecnej głównie w prasie, ale także w nowych mediach, czyli na różnych platformach internetowych i portalach społecznościowych. Wszystkie dziennikarki zostały ukształtowane w kraju - od dwudziestolecia międzywojennego poprzez PRL i wolną Polskę po transformacji ustrojowej $1989 \mathrm{r}$.

Należy dodać, że spośród polskich dziennikarzy pokolenia „niezłomnych", działających na terenie Wielkiej Brytanii, którzy na trwałe wpisali się w świadomość polskiej diaspory rozsianej po całym świecie, wymienić należy szczególnie: Antoniego Bogusławskiego, Aleksandra Bregmana, Zdzisława Broncla, Macieja Cybulskiego, Krystynę Cywińską, Witolda Czerwińskiego, Marię Danilewicz-Zielińska, Macieja Fedhuzena, Ryszarda Kiersnowskiego, Stefanię Kossowska, Zygmunta Nowakowskiego, Juliusza Sakowskiego, Antoniego Wasilewskiego, Wiesława Wohnouta, Tadeusza Zabłockiego, Wacława Zagórskiego, Wacława A. Zbyszewskiego, Karola Zbyszewskiego, Tadeusza Żenczykowskiego-Zawadzkiego $\mathrm{i}$ in. Niektórzy doczekali się przypomnienia, inni jeszcze nie ${ }^{2}$. Ponieważ Krystyna Cywińska po przejściu z londyńskiego „Dziennika Polskiego

2 Katarzyna Bzowska-Budd (red.), Dopóki jest „Dziennik” - jestem..., (Londyn: Polska Fundacja Kulturalna, 2000); Jolanta Chwastyk-Kowalczyk, „Antoni Bogusławski - the forgotten journalist, poet, writer, translator, author of children literature, literary critic, oficer”, Rocznik Historii Prasy Polskiej, t. 21, z. 1(19), 2018, 5-21; eadem, „Maria Danilewicz-Zielińska i Stefania Kossowska - niezapomniane postacie kultury polskiej”, w: Urszula Kozłowska, Tomasz Sikorski, Adam Wątor (red.), Obywatelki na obcasach. Kobiety w życiu publicznym (XIXiXX w.), t. 1, (Radzymin-Warszawa: Wydawnictwo von borowiecky, 2016), 227-244; Halina Taborska, Ewa Lewandowska-Tarasiuk (red.), The Hanna \& Zdzisław Broncel Charitable Trust-fundatorzy, powiernicy beneficjenci, (Londyn: PUNO Press, 2016). 
i Dziennika Żołnierza” w 2007 r. do opiniotwórczego „Nowego Czasu” tytułu stworzonego przez nowa falę emigracji lat 80. XX w. - stała się symbolem łączacym dawna emigrację $z$ młoda, uznano, że należy poszerzyć wiedzę na temat sposobu uprawiania przez nią dziennikarstwa. Analizie jakościowej poddano 119 felietonów jej autorstwa, które zostały opublikowane w „Nowym Czasie” w latach 2007-2017.

Krystyna Cywińska urodziła się 6 października 1925 r. w Warszawie (6 października 2006 r. ukazał się pierwszy numer „Nowego Czasu”). Jak podaje biogram w Muzeum Powstania Warszawskiego, „Wydra” (pseud. Cywińskiej) należała do Armii Krajowej, batalion „Kiliński” - 1. kompania „Wigry” - pluton 162. Od 17 sierpnia w zgrupowaniu „Hal” - kompania szturmowa - I pluton; brała udział w powstaniu warszawskim. Była jeńcem Stalagu 344 Lamsdorf, po wyzwoleniu przebywała w obozie tymczasowym w Meppen.

Po wyzwoleniu pozostała na Zachodzie. Od maja 1945 r. służyła w dowództwie 1. Dywizji Pancernej gen. Stanisława Maczka. W 1947 roku przeniesiona do Anglii, gdzie służyła do demobilizacji. W Londynie ukończyła studia polonistyczne na Polskim Uniwersytecie Na Obczyźnie (PUNO), a następnie pracowała jako dziennikarz: w latach 19521956 w Radio Wolna Europa, w latach 1956-1996 w World Service $\mathrm{BBC}^{3}$.

27 września 1947 r. w Guildford poślubiła Janusza Cywińskiego, w powstaniu warszawskim żołnierza batalionu „Oaza” na Sadybie Mokotowie. Została odznaczona Krzyżem Oficerskim Orderu Zasługi RP oraz Krzyżem Oficerskim Orderu Odrodzenia Polski.

Od lat 50 XX w. do 2006 r. była filarem londyńskiego „Dziennika Polskiego i Dziennika Żołnierza”. Na jej felietony czekali czytelnicy, jak kiedyś na teksty Zygmunta Nowakowskiego. Cechuje ją bogate doświadczenie, erudycja, kultura literacka i osobista. Jej pióro obrazuje żywy język. Potrafi prowadzić spory intelektualne i polityczne, unikając typowej w polskiej debacie publicznej agresji. „Krystyna Cywińska jest felietonistka rasowa $z$ bardzo ostrym pazurem, $z$ wrodzonym darem polaryzowania postaw, pozbawionym moralizatorstwa" ${ }^{4}$. Przez 50 lat

3 Powstańcze biogramy: Krystyna Wyderko. Online: http://www.1944.pl/powstanczebiogramy/krystyna-wyderko,50448.html [online] [dostęp: 22.08.2017]. Dostępny w World Wide Web: <http://www.1944.pl/powstancze-biogramy/krystyna-wyderko,50448.html> 4 Grzegorz Małkiewicz, „Felietonistka z pazurem”, Nowy Czas, October/223, 2016, 15. 
uprawiania dziennikarstwa wypracowała swój własny publicystyczny styl komentowania rzeczywistości społeczno-politycznej, najczęściej Polaków żyjących na emigracji. Często pretekstem do skupienia jej uwagi sa fragmenty banalnej, wydawać by się mogło, rzeczywistości. Autorka potrafi instynktem dziennikarskim penetrować rozmaite tematy i zdarzenia. Syntetyzuje w swych tekstach postawy naszych rodaków, z którymi identyfikują się czytelnicy.

Dzięki wytężonej, systematycznej pracy powstał imponujący „dorobek prozatorski, świadectwo epoki, który nie straci nic ze swej aktual-

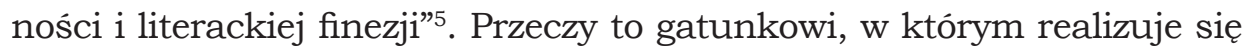
po mistrzowsku Krystyna Cywińska-żywot felietonu bowiem jest krótki, jak i wydarzenia, które opisuje. Jednak jej artykulacje się nie przeterminowują. Świadczą o doskonałym słuchu językowym. Dziennikarka krótko, ale celnie tytułuje swoje teksty. Reprezentuje charakterystyczny typ humoru, refleksyjny i podszyty sarkazmem. Polemika dla niej jest „dusza publicystyki”. W jednym $z$ felietonów przyznała, że warsztatu dziennikarskiego uczył ja publicysta, eseista i znawca literatury Juliusz Sakowski, który w latach rozkwitu emigracji niepodległościowej był „magiem i ojcem

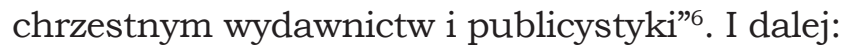

Publicystyka jest wyższym stopniem dziennikarskiego nałogu. Jest, czy powinna być rodzajem politycznego czy społecznego reflektora. Publicyści są odrębną kategorią. Sa klasa dziennikarzy sięgających do trzewi problemów politycznych czy społecznych. ... A felietoniści? Felieton to refleksja pisana pod wrażeniem chwili, czegoś czy kogoś. To czasem gawęda, czasem esej, czasem także scenka na kilka głosów. Felieton powinien być lekko ironiczny, lekko sentymentalny i dowcipny. Powinien też wnieść jakąś wiedzę. Historyczna, literacka, polityczną. Dla równowagi. ... Ideałem felietonu jest lekkość, lapidarność i dawka cynizmu ${ }^{7}$.

Teksty Krystyny Cywińskiej dotykaja kwestii elementarnych, uniwersalnych, dotyczących każdego żyjącego człowieka na obczyźnie, nie tylko Polaków. W swoich felietonach unika nachalnego politycznego zaangażowania. Dzięki swej wyjątkowej otwartości stała się pomostem

\footnotetext{
Ibidem.

6 Krystyna Cywińska, „Dziennikarskie hieny”, Nowy Czas, nr 19 (176), 2011, 10.

7 Ibidem.
} 
łączącym czytelników pokolenia "niezłomnych” z nowymi przybyszami z Polski na Wyspy Brytyjskie. To ona, dołaczając do redakcji „Nowego Czasu" kilka miesięcy po powstaniu tygodnika, zdobyła wielu nowych czytelników spośród młodej generacji emigrantów poakcesyjnych, zatrzymując jednocześnie tych, którzy pamiętali jej felietony $z$ londyńskiego „Dziennika Polskiego i Dziennika Żołnierza” oraz jego sobotniego wydania „Tygodnia Polskiego”. W jednym $z$ felietonów przekornie nazwała swoje pokolenie „mastodontem jurajskiej epoki w modnie rozchełstanym tłumie", czyli wśród młodej generacji pounijnych emigrantów. Swoim pisaniem przełamuje uprzedzenia między Polską a emigracją.

Jej pierwszy felieton w „Nowym Czasie” pt. Bez języka ukazał się w marcu w 9 numerze 2007 r. (s. 10) ${ }^{9}$. Autorka opisała w niej zabawne sytuacje, jakie wynikały $z$ powodu nieznajomości języka angielskiego przez przedstawicieli pokolenia "niezłomnych” w pierwszym okresie pobytu w Wielkiej Brytanii, oraz ślady polskiej obecności w Szkocji. W następnym numerze redakcja zadowolona ze współpracy $z$ doświadczona dziennikarka na pierwszej stronie wytłuszczonymi literami zachęcała czytelników: „Nie trać czasu! Czytaj Krystynę Cywińską w «Nowym Czasie»"10. Ten szacunek i czynna współpraca trwaja do dzisiaj.

Po pięciu latach współpracy z „Nowym Czasem” w 2011 r. oznajmiła, że nie wyobraża sobie życia bez tego pisma. Bez tych szpalt, na których tak mi dobrze, wygodnie i do twarzy. Odeszłam $z$ „Dziennika Polskiego i Dziennika Żołnierza”. ... Poszłam jak w dym za smugą talentu i wrażliwości publicystycznej Grzegorza Małkiewicza. ... Nie wykorzystano, rozmyślnie czy nieumyślnie, w tym dzienniku jego wiedzy, wnikliwości, wrażliwości i kultury osobistej. Skazano go tam na wegetację. Cała reszta życiorysu Grzegorza w „Dzienniku Polskim i Dzienniku Żołnierza" jest świadectwem złych obyczajów. Typowych dla polskiego piekiełka bez granic. Grzegorzowi i jego żonie Teresie udało się jednak stworzyć swoje pismo. Swój Nowy Czas. Otworzyć jego szpalty dla nowych i starych autorów, starych i nowych czytelników, i nie tylko. Stworzyli przecież razem ARTerię dla twórczych rąk i głów. Czuję się

8 Eadem, „Minusowy plus”, Nowy Czas, nr 25 (90), 2007, 12.

9 Jednak dopiero w maju 2007 r. zadeklarowała się na łamach pisma jako jego stała felietonistka: Krystyna Cywińska, „Donoszę, że...”, Nowy Czas, nr 18 (30), 2007, 12.

10 Nowy Czas, nr 10 (22), 2007, 1. 
szczęśliwa, że moje życie dobiegające końca felietonistycznych fanaberii jest na tym finiszu $z$ nimi zwiazane ${ }^{11}$.

Mimo 94 lat Krystyna Cywińska ma znakomita pamięć, z powodzeniem uprawia językowa ekwilibrystykę, ma poczucie humoru i wyjatkowo bystry zmysł obserwacji w tych dynamicznie zmieniajacych się czasach. Czytelnicy czekają na jej felietony, a pytana, jak to robi, że pisze takie teksty, wyłożyła swoje credo dziennikarskie:

Trzymam się zasad. Najpierw się czymś wkurzam, potem reflektuję. Po czym nie nudzę, nie pouczam, nie gładzę ani nie bajdurzę. Nie używam przymiotników, nie kłaniam się byle komu, a zwłaszcza notablom. Mam dystans do wszystkiego, co mnie otacza. A przede wszystkim nie boję się krytyk ani kontrowersji. I nie chcę się rozkładać na całej stronie pisma. Bo felietonista, który rozkłada się na wielu szpaltach, kopie sobie grób poczytności ${ }^{12}$.

Zawsze apelowała na łamach prasy o rzetelność dziennikarska, ostro krytykowała niechlujstwo i nieznajomość historii osób piszacych w polskich czasopismach wydawanych na emigracji ${ }^{13}$. Wyraziła opinię, że dziennikarstwo polonijne jest specyficzne, „chodzi w nim o posiadanie nosa na czytelników. ... Jest w większości amatorskie, bywa, że chałupnicze. ... Dziennikarstwo to dziś sztuka stosowana. W wolnym kraju każdy może wyrazić swoje zdanie i nikt nie musi tego słuchać ani czytać. W dziennikarstwie naczelna zasada jest nie nudzić, nie nudzić i jeszcze raz nie nudzič"14. Polemika dla niej jest „dusza publicystyki”" ${ }^{\text {. Ceni }}$ sobie polemiki z Grzegorzem Małkiewiczem, jakie prowadza na łamach „Nowego Czasu” od lat: „Jesteśmy w tym polemicznym tandemie odbiciem obyczajów angielskich. Potrafimy rozmawiać. Listownie, osobiście, a nawet przez telefon. Nie wymyślamy sobie nawzajem, nie złorzeczymy i nie odsądzamy od czci i wiary” ${ }^{16}$. Przyznała, że „w BBC nas uczono, że

\footnotetext{
11 Krystyna Cywińska, „Piątka z plusem”, Nowy Czas, nr 15 (172), 2011, 17.

12 Eadem, „Zenk you, że mnie czytacie”, Nowy Czas, nr October/223, 2016, 13.

13 Eadem, „Tere-fere kuku”, Nowy Czas, nr 19 (31), 2007, 10; eadem, „Krytykując, czyli plując, trując i szkalując”, Nowy Czas, nr 2 (212), 2015, 15; eadem, „Patriotyczna fanfaronada $z$ domieszka fantazji", Nowy Czas, nr 3 (213), 2015, 11.

14 Eadem, „Co donosi echo?”, Nowy Czas, nr 23 (35), 2007, 8.

15 Eadem, „Partykularz”, Nowy Czas, nr 5 (70), 2008, 12.

16 Eadem, „Strzela baba z łuku”, Nowy Czas, nr 6 (163), 2011, 10.
} 
w dziennikarstwie najważniejsze jest po pierwsze: sprawdzanie faktów. Po drugie: bezstronność. I po trzecie: umiar"17.

Będąc formalnie obywatelka brytyjska, wielokrotnie $z$ troska pochyla się nad zachowaniem czystości i poprawności języka polskiego na emigracji ${ }^{18}$, uważając, że „Na obczyźnie język jest ojczyzną. Bo w języku można żyć i się wyżywać. ... Żadne pozowanie na tubylców ani udawanie, że się własnego języka zapomniało nie pomoże"19. Przypominała, że dzięki miłości do języka ojczystego, który był spoiwem rodaków - pokolenie „niezłomnych” na emigracji przetrwało na ziemi brytyjskiej, że dzięki niemu mamy polskie kościoły, polskie domy, teatry, POSK i Ognisko w Londynie. Dostrzega jednak symptom czasu, że obecnie słyszany często na londyńskiej ulicy język polski „stacza się powoli do rynsztoka”, a na zadane retoryczne pytanie: "Co by było, gdyby to Polak stworzył świat?”, odpowiada: „Wszyscy by pewnie klęli jak szewc po polsku. I po polsku wrzeszczeli na ulicach pod latarniami i w pubach by rozrabiali”20.

Wypowiadała się na temat wpojonego Polakom posłannictwa szerzenia kultury polskiej, martyrologii, folkloru, kuchni za granica. Zalecała umiar i przede wszystkim „uczenie się kultury od innych”21. Dystansowała się do nostalgicznej tęsknoty za krajem, który istnieje tylko w imaginacji emigrantów i twardo stała na stanowisku, że „będzie jednak się wsłuchiwać w polski język na ulicach Londynu"22. Przewrotnie $\mathrm{z}$ sarkazmem odnotowała różnicę $\mathrm{w}$ postrzeganiu ojczyzny przez młode pokolenie emigrantów a pokolenie „niezłomnych”:

Polacy na obczyźnie szczególnie Polskę kochaja. Miłościa platoniczna. Bez ryzyka życia w kraju. Na dogodna odległość, bez narażania tej miłości na rozczarowania. My na emigracji kochaliśmy Polskę nad życie, za komuny nienawidząc PRL-u. Kochaliśmy ją w granicach przedwojennych. Nie akceptując granic jałtańskich. Choć Wrocław, Opole i Mazury owszem też. Miłość do ojczyzny zawsze się mieściła w różnych

\footnotetext{
17 Eadem, „A w mediach gadu gadu...," Nowy Czas, nr 7-8 (193-194), 2013, 10.

18 Eadem, „Bajeczko o...”, Nowy Czas, nr 21 (33), 2007, 8; eadem, „Pong-mowa”, Nowy Czas, nr 27 (92), 2008, 12; eadem, „No i super”, Nowy Czas, nr May/June/230-231, 2017,13 .

19 Eadem, „Zenk you, że mnie czytacie”.

20 Eadem, „Język pod latarnia”, Nowy Czas, nr 26 (38), 2007, 8.

21 Eadem, „Posłannictwo”, Nowy Czas, nr 10 (22), 2007, 10.

22 Eadem, „Peregrynacja”, Nowy Czas, nr 11 (23), 2007, 10.
} 
granicach. No a teraz musi się zmieścić bez granic. ... Jestem hobbystką polskości. Każdy z nas kocha nasz kraj po swojemu ${ }^{23}$.

Przybliża czytelnikom obyczajowość brytyjska, z jej podziałami klasowymi i powściagliwością, która nowo przybyli nazywaja hipokry$z_{j a}{ }^{24}$. Na wiele lat przed ogłoszeniem brexitu gorzko krytycznie oceniła nowe fetysze brytyjskiej poprawności politycznej - liberalizm i integrację - pojęcia pozbawione treści i zdegenerowane przez rzeczywistość25. Napisała: „Taki dualizm generuje życie przybyszy w "rozkroku” [...] w emigracyjnym kotle. Jedni noga w Pakistanie, inni w Indiach czy w Bangladeszu, na Bliskim czy Dalekim Wschodzie. A my w Polsce"26. Nurtuje ja następująca kwestia: „Jak to jest $z$ tym nagłym, nieoczekiwanym, złym traktowaniem Polaków w angielskiej krainie zwanej tolerancją?"27.

Zainteresowała się także wyobcowaniem $z$ polskości pokolenia rodaków urodzonych na Wyspach Brytyjskich, które nie poczuwa się do obowiąku zachowania ciagłości polskich instytucji emigracyjnych ${ }^{28}$. Cyklicznie piętnowała polski antysemityzm w kraju i na emigracji ${ }^{29}$ oraz ciasny, parafialny nacjonalizm ${ }^{30}$. Na łamach „Nowego Czasu” łajała urzędników polskiej ambasady w Londynie przy okazji zorganizowania rocznicowego wieczoru poświęconego Irenie Sendlerowej w 2009 r., na którym zabrakło dziennikarzy „Daily Mail” i „Timesa”, zarzucajacych Polakom antysemityzm, polskich księży i przedstawicieli niemieckiej ambasady $^{31}$. Zirytowana stwierdziła, że:

A zgodnie $z$ cytowaną na tych szpaltach zasada, że jak coś można spieprzyć, to spieprzymy, w ambasadzie też spieprzono. Bo krótki film o Pani Irenie i uratowanej przez nią Elżbiecie Ficowskiej raz po raz

\footnotetext{
${ }_{23}$ Eadem, „Polskie hobby”, Nowy Czas, nr 2 (67), 2008, 12.

24 Eadem, „Shibboleth”, Nowy Czas, nr 17 (29), 2007, 10; eadem, „Stereotyp w błocie”, Nowy Czas, nr 44 (109), 2008, 14; eadem, „Niesmak i smak nienawiści”, Nowy Czas, nr 8 (185), 2012, 10; eadem, „Jak równy z równym”, Nowy Czas, nr 1 (187), 2013, 10.

25 Eadem, „Konkubinat”, Nowy Czas, nr 29 (41), 2007, 8.

26 Eadem, „Życie w rozkroku”, Nowy Czas, nr 36 (48), 2007, 8.

27 Eadem, „Nowe okulary kupię”, Nowy Czas, nr 1 (199), 2014, 10.

28 Eadem, „Skrzek”, Nowy Czas, nr 20 (32), 2007, 12.

29 Eadem, „Donosy o donosach”, Nowy Czas, nr 31 (96), 2008, 12; eadem, „Prawda czy półprawdy?”, Nowy Czas, nr 3 (160), 2011, 10; eadem, „Trefnie czy trafnie?”, Nowy Czas, nr 10 (167), 2011, 10; eadem, „Dwie ojczyzny”, Nowy Czas, nr 2 (179), 2012, 10; eadem, „Świątecznie i nieświątecznie”, Nowy Czas, nr 9 (186), 2012, 12.

30 Eadem, „Oskarżenia czy zarzuty?”, Nowy Czas, nr 3 (68), 2008, 12.

31 Eadem, „Oskarżenia czy zarzuty?”, Nowy Czas, nr 9 (125), 2009, 10.
} 
dostawał czkawki. Parę razy nawet zawył żałośnie ... Ale dzięki obecności na wieczorze Elżbiety Ficowskiej, Lili Pohlmann i jej męża duch Pani Ireny wszedł w serca obecnych ${ }^{32}$.

Krystyna Cywińska w swoich felietonach namawiała do autoana$\mathrm{lizy}^{33}$, do tolerancji ${ }^{34}$. Ta przewrotna felietonistka rozumie, co to znaczy być uchodźca czy emigrantem, w swoich tekstach wychodzi poza polski prowincjonalizm. Nie roztkliwia się nad losem emigranta. Przestrzega, że Wielka Brytania weryfikuje naszych rodaków, ich myślenie, postawy i stereotypy. Apeluje, by „oczyścili się z pokładów zaszłości, podłości, zakłamania i nienormalności”, $z$ dala od polskich polityków, którzy kolonizuja, niczym „mentalne liliputy”, cała sferę publiczną ${ }^{35}$. Namawiała Polaków, by czynnie włączyli się w życie polityczne, żyjąc na emigracji, choćby uczestniczeniem w wyborach ${ }^{36}$. Tłumaczyła, czym jest brytyjskośćc ${ }^{37}$. Za Marianem Hemarem [właśc. Hescheles Marian, pseud. Haryman, Jan Maziarski] piętnowała chorobę emigracji, jaka jest „ciagłe rozgrzeszanie nieudolności, amatorstwa, szmiry, dyletantyzmu i niedbalstwa w imię tzw. trudności i ciężkich warunków pracy"38. Nie zapominała o refleksjach na temat świąt obchodzonych przez Polaków ${ }^{39}$, ale także o „wycofywaniu się $z$ tradycji i obyczajów religijnych za ściany swoich domów"40. $Z$ troska pisała o patologii społecznej, w tym o przemocy domowej, konstatujac: „Dziennikarstwo, ... stało się obrabiarka politycznych plew i odgrzebywanych tematów. A życie ludzkie jest skazane na własny rachunek i rozrachunek $z$ przeciwnościami”41.

\footnotetext{
32 Ibidem.

33 Eadem „Upupi i obłupi?”, Nowy Czas, nr 8 (72), 2008, 12.

34 Eadem, „Ku przestrodze”, Nowy Czas, nr 4 (120), 2009, 14; eadem, „Do Siego itd.”, Nowy Czas, nr 1 (137), 2010, 10; eadem, „Mój stan zawieszenia”, Nowy Czas, nr 3 (189), 2013, 10; eadem, „Wszystkie nasze dzienne sprawy”, Nowy Czas, nr April/229, 2017, 11. 35 Eadem, „Karłowatość”, Nowy Czas, nr 12 (24), 2007, 10; eadem, „Politycy i psychole”, Nowy Czas, nr 16 (152), 2010, 12.

36 Eadem, „Do urn”, Nowy Czas, nr 42 (54), 2007, 8; eadem, „Demony demokracji”, Nowy Czas, nr 4 (140), 2010, 10; eadem, „Ciemna masa”, Nowy Czas, nr 8 (144), 2010, 14.

37 Eadem, „Brytyjskość”, Nowy Czas, nr 47 (59), 2007, 12; eadem, „Pokłonu nie złożono”, Nowy Czas, nr 6 (183), 2012, 10.

38 Eadem, „Farsa w POSK-u”, Nowy Czas, nr 49 (61), 2007, 12.

39 Eadem, „Zaduszki”, Nowy Czas, nr 44 (56), 2007, 8.

40 Eadem, „Credo”, Nowy Czas, nr 51-52 (63-64), 2007, 14.

41 Eadem, „Płonne nadzieje”, Nowy Czas, nr 7 (185), 2012, 12.
} 
Uzmysławia, że polityka to nie świętych obcowanie, przestrzegała przed „dziką lustracja” w Polsce ${ }^{42}$, komentowała informacje o współpracy ze Służba Bezpieczeństwa znanych postaci życia polskiej diaspory na świecie, nie tylko w Wielkiej Brytanii ${ }^{43}$. Uważa, że nasz kraj jest uwięziony w obsesjach polityków różnych opcji, spychany na peryferie Europy. Pisała o Instytucie Pamięci Narodowej ${ }^{44}$. Piętnowała pierwsze doniesienia w 2008 r. i późniejsze ${ }^{45}$ na temat współpracy Lecha Wałęsy $z$ bezpieka, że „żadne szarganie ani brzydkie szafowanie jego imieniem, słusznie czy nie, nie pozbawi go wielkości”46. W innym felietonie dodała: „Okropnie to gorszące, te ataki na Wałęsę. I co sobie pomyśli o nas Zachód? ... Cieszmy się, że mamy za bohatera Lecha Wałęsę, niezależnie od tego, co kto o jego intelekcie czy przeszłości sądzi”" ${ }^{27}$. Prowokująco zwróciła się do polityków w Polsce: „Odebraliście nam wiarę w godność i rozwagę obywatelska. Wyborcy powinni was przegonić z Sejmu. Surowo was, polityków, zlustrować, opierając się nie na pogłoskach i wątpliwych dokumentach, nie na nienawiści i szkalowaniu, ale na racjonalnym przeglądzie waszych dokonań"48.

Wielokrotnie pisała o warcholstwie politycznym ${ }^{49}$, wyborach samorzadowych, parlamentarnych i prezydenckich w kraju, w tym prowadzonych kampaniach polityków krajowych podczas wizyt w Wielkiej Brytanii $^{50}$. W 2010 r. przestrzegała: „Pamiętajcie moi drodzy, że kto w tym polowaniu na urząd prezydencki zwycięży, padnie wkrótce ofiarą nagonki ogarów. Już poszły w las"51.

Po podróży do Warszawy w 2008 r. wypowiedziała się także na temat zmian w Polsce, zaskoczona skokiem cywilizacyjnym, jaki dokonał się w młodym pokoleniu Polaków w kraju:

\footnotetext{
42 Eadem, „Rozliczanie”, Nowy Czas, nr 13 (25), 2007, 10.

43 Eadem, „Niedosyt informacji”, Nowy Czas, nr 2 (159), 2011, 12.

44 Eadem, „Inkwizycja”, Nowy Czas, nr 16 (28), 2007, 10.

45 Eadem, „Worek Judaszy”, Nowy Czas, nr 7 (123), 2009, 10.

46 Eadem, „Inkwizycja”, Nowy Czas, nr 22 (87), 2008, 12.

47 Eadem, „Powtórki z przeszłości”, Nowy Czas, nr 26 (91), 2008, 12.

48 Eadem, „Niedosyt informacji”, Nowy Czas, nr 2 (159), 2011, 12.

49 Eadem, "Wkurzenie”, Nowy Czas, nr 34 (46), 2007, 8.

50 Eadem, „Galopujący Gallup”, Nowy Czas, nr 37 (49), 2007, 8; eadem, „Diabolizm”, Nowy Czas, nr 40 (52), 2007, 8; eadem, „Kociokwik”, Nowy Czas, nr 9 (145), 2010, 10; eadem, „Święte krowy”, Nowy Czas, nr 10 (146), 2010, 14.

51 Eadem, „Polowanie z nagonką, Nowy Czas, nr 11 (147), 2010, 12.
} 
Tak, proszę starej emigracji! Nowe, przedsiębiorcze pokolenia polskie wyprzedziły naszą o nich wyobraźnię. ... My tu, stara emigracja, nie widzimy masy polskiej inteligencji w średnim wieku. Wykształconej, oświeconej, gadającej językami, przedsiębiorczej. I w niczym nie ustępującej zawodowo ani środowiskowo społecznościom zachodnim. Może nawet bardziej od nich głodni wiedzy i doświadczeń. Powoli wypełniajaccej wyrwy i wykroty po wydartych przez wojnę i Sowiety korzeniach polskiej inteligencji ${ }^{52}$.

By zaraz dodać, że czas nie zniwelował jednak resztek polskiej ksenofobii, puentując, że „Europa jest wprawdzie bez granic, ale ksenofobia bywa bezgraniczna" ${ }^{33}$. Transmisja Eurowizji w 2008 r. utwierdziła ją w przekonaniu, że w Europie odradza się szowinizm. „A te flagi nad głowami sa czymś w rodzaju symboli ksenofobii. Krucha jest różnica między narodowa dumą a narodową buta" ${ }^{54}$.

Krystyna Cywińska pięknie wypowiadała się na temat Powstania Warszawskiego, uważając, że „Większość wspomnień - albo przerasta ówczesna rzeczywistość, albo jej nie dorasta. Nawet spisana na gorąco historia tego zrywu też bywa niedokładna, przerysowana, niedorysowana. Czasem żarliwie broniąca pozycji, postaw, decyzji nie do obronienia" ${ }^{\text {5 }}$. Powracała niechętnie, ale jednak cyklicznie ${ }^{56}$ do wspomnień $z$ tamtego czasu podczas wieczorów w Ognisku Polskim, do zaciekawionego jej przeżyciami powstańczymi i obozowymi gen. Andersa ${ }^{57}$ oraz przy innych okazjach rocznicowych ${ }^{58}$. Pisała także o relatywizmie historii ${ }^{59}$. Czasami wracała myślami do początków swego pobytu w Wielkiej Brytanii, porównywała polska emigrację niepodległościowa $z$ ta poakcesyjną i wzajemne relacje $z$ Anglikami i Szkotami ${ }^{60}$.

52 Eadem, „Krótka piłka”, Nowy Czas, nr 20 (85), 2008, 14.

53 Ibidem.

54 Eadem „Wet za wet”, Nowy Czas, nr 21 (86), 2008, 12.

55 Eadem, „Bum, bum”, Nowy Czas, nr 31 (42), 2007, 8.

56 Eadem, „Dziewczyny w okryjbidkach”, Nowy Czas, nr 13 (148), 2010, 10.

57 Eadem, „Złota starość”, Nowy Czas, nr 12 (128), 2009, 10.

58 Eadem, „Wielbiciele mitów”, Nowy Czas, nr 9 (195), 2013, 10; eadem, „Miasto nieposkromione”, Nowy Czas, nr 7 (205), 2014, 16; R.A. Gazdziński, „Londyńskie wspomnienia powstańców [1]", Nowy Czas, nr 7 (205), 2014, 17.

59 Krystyna Cywińska, „Majowe refleksje”, Nowy Czas, nr 5 (203), 2014, 10.

60 Eadem, „Polsko-szkockie krewkie życie”, Nowy Czas, nr 8 (206), 2014, 1. 
Dostrzegała rozwój stolicy po 1989 r., otrząsającej się z przeszłości socrealizmu ${ }^{61}$. Zawsze piętnowała jednak u polskich polityków i ich otoczenia brak ogłady, dobrego wychowania, oczekujacc kultury, elegancji, dyskrecji czy nieskazitelnych manier ${ }^{62}$.

Analizowała pojęcie patriotyzmu ${ }^{63}$. Również przy okazji prezydenckich wyborów w USA, kiedy o fotel głowy państwa w 2008 r. walczyli demokrata Barack Obama i republikanin Joe McCaine ${ }^{64}$. Zastanawiała się, który byłby większym sprzymierzeńcem Polski. Sarkastycznie opisała w okresie kampanii wyborczej w wyborach powszechnych w Wielkiej Brytanii 2010 r. niewiedzę kandydatów na posłów zabiegających o głosy Polaków - na temat zbrodni katyńskiej, przyznała, że:

wpadłam w rozmowie telefonicznej w szał historyczno-polityczny i wygarnęłam w tym szale nasze gorzkie żale do Churchilla i kolejnych premierów brytyjskich. I choć my, Polacy, obywatele tego kraju głosowaliśmy przez te lata w kolejnych wyborach, niczego nie wskóraliśmy $\mathrm{w}$ tej jatrzącej się sprawie. Robiono nam nawet trudności w planach postawienia pomnika katyńskim ofiarom. Stanał w końcu na cmentarzu w Gunnersbury w Londynie, ale nie wolno było na nim napisać, że mordu dokonali na rozkaz Stalina i NKWD żołnierze sowieccy. Strzałem w tył głowy. Nasz miejscowy liberał milczał. ... Ale głosować pójdę

Po katastrofie smoleńskiej $z$ wielkim szacunkiem wspominała Prezydenta Lecha Kaczyńskiego:

To on, organizując dumne obchody 60. rocznicy Powstania Warszawskiego, przywrócił Polakom poczucie godności narodowej. To on przyczynił się do zbudowania Muzeum Armii Krajowej. To on siegnał do patriotycznych trzewi narodu. To on ruszył do rozrachunku ze strukturami postkomuny. $Z$ ostatecznym zerwaniem $z$ poprzednim systemem i jego wypaczeniami. I stał się za to przedmiotem zajadłej nagonki przeciwników ${ }^{66}$.

\footnotetext{
61 Eadem, „Miasto nieposkromione”, Nowy Czas, nr 30 (95), 2008, 12; eadem, „Dwa łona”, Nowy Czas, nr 14 (130), 2009, 12.

62 Eadem, „Wielbiciele mitów”, Nowy Czas, nr 11 (197), 2013, 12.

63 Eadem, „Polski patriotyzm”, Nowy Czas, nr 28 (93), 2008, 12; eadem, „Niezgodna zgodna”, Nowy Czas, nr 43 (108), 2008, 12; eadem, „Wojenna glatwa”, Nowy Czas, nr 3 (201), 2014, 12.

64 Eadem, „Narkotyk polityczny”, Nowy Czas, nr 36 (101), 2008, 14.

65 Eadem, „Zaciskanie politycznego pasa”, Nowy Czas, nr 6 (142), 2010, 10.

66 Eadem, „Polały się łzy”, Nowy Czas, nr 7 (143), 2010, 14.
} 
$Z$ wielkim smutkiem i niedowierzaniem pisała o Polsce w tamtym okresie, że „coś w niej pękło, że jad się sączy. Jad nienawiści na grobach w Smoleńsku. Jad zwątpienia w prawdę o ich śmierci. Tych zdradzonych o świcie - jak poetę Herberta zacytował Jarosław Kaczyński. Dziś zdradzanych przez polityczne rozgrywanie ich smierci" ${ }^{67}$.

Jednocześnie zmierza się $z$ jakże aktualnym problemem współczesnego terroryzmu islamskich fundamentalistów, także falą emigrantów napływających do Europy Zachodniej ${ }^{68}$. Dostrzegła, że społeczeństwo brytyjskie i nie tylko ma poważne problemy: „Jak się teraz uporać ze skutkami papki, dyrdymałów o wielokulturowości, wielorasowości i wieloreligijności. Okazuje się, że za dużo tego wielo... Poprawność polityczna stanęła teraz ludziom kością w gardle" ${ }^{\text {. W }}$. Wączając się do dyskusji na temat skutków napływu emigrantów $z$ różnych stron świata do Zjednoczonego Królestwa, wyrażała niejednokrotnie opinię, że: „Prawdziwym zagrożeniem dla tego kraju sa radykalni muzułmanie. Religijni ekstremiści i terroryści"70. Nawet opisując swoje wrażenia ze ślubu księcia Williama (książę Cambridge, właśc. William Arthur Philip Louis) z Kate Middleton w 2011 r. zauważyła, że przy trasie orszaku weselnego w Londynie wśród rozentuzjazmowanego tłumu nie dostrzegła „ani jednego muzułmanina, ... ani jednej kobiety w czadorze, burce czy chuście na głowie. W kraju, który miał być multi-kulti? Zjednoczony w masie i rasie, okazał się nagle zjednoczony w białych twarzach. Okazało się czarno na białym, że większość czarnych i czekoladowych mieszkańców tego kraju jest wyobcowana" ${ }^{71}$.

Eskalacja zamieszek w 2011 r. w Anglii zradykalizowała jej poglady na nakaz bezwzględnej tolerancji, napisała wprost: „Ten kraj zaczyna się ruszać i budzić $z$ letargu otępiałej tolerancji i tej banalnej poprawności. Niedawno ukazało się ogłoszenie o poszukiwaniu lekarza do szpitala w Liverpool. Na końcu ogłoszenia dodano: $z$ uwzględnieniem idiotycznych przepisów o równouprawnieniu ras, religii i płci. Czyli the usual

67 Eadem, „Wirtualne zmory”, Nowy Czas, nr 7 (164), 2011, 10.

68 Eadem, „Przetrwamy”, Nowy Czas, nr 27 (39), 2007, 8; eadem, „Zaleją nas, czy nie zaleją?”, Nowy Czas, nr 7 (216), 2015, 17; eadem, "Czy podzielimy los starożytnych Rzymian?”, Nowy Czas, nr 9 (218), 2015, 13; eadem, "Trochę nostalgii w Nowy Rok”, Nowy Czas, nr 1 (219), 2016, 15.

69 Eadem, „Odwieczna paplanina”, Nowy Czas, nr 19 (135), 2009, 14.

70 Eadem, „W realu”, Nowy Czas, nr 3 (139), 2010, 10.

71 Eadem, „Czwarty świat”, Nowy Czas, nr 8 (165), 2011, 12. 
rubbish"72. Po kilku latach jeszcze bardziej utwierdziła się w swoim przekonaniu co do muzułmanów. Według niej wyznawcy islamu „Etnicznie zapewne szybko się nie zasymilują. Będą żyć i rozmnażać się w gettach. Lewackie bajdurzenie o społeczeństwa zintegrowanych - multi-kulti dawno już zbankrutowały"73.

Odnotowuje zmiany obyczajowe po napływie emigrantów różnych narodowości, $z$ którymi Wielka Brytania radzi sobie rozmaicie. W swoim felietonie przytoczyła następujący fragment, który przeczytała w „Daily Telegraph”: „bezczelny ruski Iwan jest już wszędzie. Panoszy się od Bałtyku po Pacyfik. Od Morza Śródziemnego po Adriatyk. I wychamia się w Anglii. Po co wojna, skoro pokojowa inwazja wystarczy. A najeźdźcy spadają w pijanym stuporze ze stołków przy angielskich barach i klna jak szewcy"74.

Publicznie przyznała, że bojkotuje dziennik „The Times” za oczerniające Polaków artykuły Gilesa Corenta, zaznaczając sarkastycznie: „Okazuje się, że jako biali Murzyni jesteśmy tu pożądani [jako przysłowiowi hydraulicy - J.C.K]. A jako potomkowie barbarzyńców, żywcem palących Żydów - napiętnowani”75. Wielokrotnie wypowiadała się krytycznie o ledwie utrzymującym się na rynku londyńskim „Dzienniku Polskim i Dzienniku Żołnierza”, będącym wiecznie na

szczudłach dotacji, z funduszy społecznych, wysyłając SOS-y do czytelników. ... Czy warto na to pismo łożyć? ... Czy nie lepiej złożyć go do grobu, skoro podobno większość jego czytelników niedowidzi, niedosłyszy i mało czym się podnieca. Skoro listy do redakcji od lat pisza ci sami pouczyciele o poprawności językowej, historycznej, politycznej, obyczajowej i swoiście pojętym patriotyzmie. No i skoro - jak twierdza niektórzy - jest to tuba PiS-owska. Pismo polityczne powinno trzymać rękę na pulsie społecznym. ... I mniej pulsować politycznie, bo to nie rola diaspory. I nie paplać byle czego za PAP-em, nie nudzić czytelnika wyleniałym, stetryczałym, zgorzkniałym Pietrzakiem ani nudnymi wywiadami z osobami trzecimi, ani mdłymi banalnymi felietonami. Nie drukujcie dyrdymałów ${ }^{76}$.

72 Eadem, „Sentimental Journey”, Nowy Czas, nr 14 (171), 2011, 10.

73 Eadem, „Zaleja nas, czy nie zaleją?”, Nowy Czas, nr 7 (216), 2015, 17.

74 Eadem, „Czwarty świat”, Nowy Czas, nr 34 (99), 2008, 12.

75 Eadem, „Wieczerza literacka”, Nowy Czas, nr 37 (102), 2007, 14.

76 Eadem, „Koszałki-opałki”, Nowy Czas, nr 18 (154), 2010, 10. 
Marzy jej się polonijny medialny pluralizm. Ale zdecydowanie nie ma zaufania do portali internetowych: „do tej nieustajacej paplaniny, pogłosek, plotek i wymysłów. I do niewybrednych czytelników, którzy wszystko przełkna i we wszystko uwierzą. I niczego nie przetrawią"77.

Kiedy latem 2011 r. brytyjskie media zajmowały się procederem podsłuchowym w bulwarowej prasie Ruperta Murdocha, Krystyna Cywińska także dodała kilka swoich przemyśleń, stwierdzając, że:

W brytyjskiej aferze medialnej najważniejszym aspektem w gruncie rzeczy nie jest proceder podsłuchów. Jest nim zbyt silne uzależnienie od lat partii politycznych i ich przywódców od koncernu Ruperta Murdocha. Trzęsienie ziemi medialnej z powodów prawnych i moralnych odsłoniło niezbyt moralne postępowanie brytyjskich polityków. W tym nierozsądne posunięcia premiera Davida Camerona ${ }^{78}$.

W dobie kryzysu światowego w brytyjskiej rzeczywistości odnotowała większą dbałość ludzi o pracę, szanowanie klienta w sklepach, petenta urzędach itp.: „Usługi stały się nagle bardziej usłużne. ... W sklepach, gdzie klient był zdany na siebie ... teraz jest obsługiwany. ... Nawet gazownia stała się ugrzeczniona. I bardziej ludzka"79.

Zdarzały się wspomnienia z czasów jej pracy w Polskiej Sekcji $\mathrm{BBC}$ w ramach tzw. World Service, która bardzo lubiła, oraz kolegów, których z nostalgią wymieniła: Zbigniewa Błażyńskiego, Jana Radomyskiego, Witolda Leitgebera, Bolesława Taborskiego, Wojciecha Płazaka, Antoniego Pospieszalskiego, Marka Żuławskiego, Lwa Sapiehę, Jana Krok-Paszkowskiego, Eugeniusza Smolara i Krzysztofa Pszenickiego ${ }^{80}$.

Zirytowana arogancją starej i nowej emigracji bardzo rzadko daje upust swemu zażenowaniu, pisząc: „Życie bujne i bogate w treści miało na emigracji wielu weteranów. Wśród nich byli intelektualiści, politycy, malarze, dziennikarze. Tętnił tu życiem spory świat polskiej kultury i tradycji. Zamknięty już w nekrologach nie tylko w emigracyjnej prasie. Zdarzało się, że pośmiertne wspomnienia czy biograficzne sylwetki ukazywały się w brytyjskiej prasie"

77 Eadem, „Fama głosi...”, Nowy Czas, nr 19 (155), 2010, 10.

78 Eadem, „Dramat czy farsa?”, Nowy Czas, nr 13 (170), 2011, 12.

79 Eadem, „Trzy po trzy”, Nowy Czas, nr 41 (53), 2007, 8.

80 Eadem, „Tu mówił Londyn”, Nowy Czas, nr 15 (131), 2009, 14.

81 Eadem, „Takie życie...”, Nowy Czas, nr 11 (168), 2011, 10. 
Nie stroni od uwag na tematy kulturalne, jak choćby wieczorów nagrodzonych literatów przez Zwiazek Pisarzy na Obczyźnie organizowanych w POSK-u, w tym Bolesława Taborskiego w 2007 r. ${ }^{82}$ Skomentowała także 65-lecie ZASP za Granica ${ }^{83}$. Głęboko poruszona zastanawiała się jako widz, nie jako recenzentka, nad monodramem Krystyny Jandy pt. Ucho, gardło, nóż, który aktorka pokazała na scenie w POSK-u jesienia 2008 r.: „czy potrzebna jest w tym dramacie taka częstotliwość przerywników na k...? ... Czy trzeba sięgać do ulicznego rynsztoka, bo tylko rynsztokowy język wyzwala człowieka $z$ bólu?"84 Ubolewała, że wulgarny, nieokiełznany język stał się językiem powszechnym. „Z odbiciem w filmach, dramatach i telewizyjnych reportażach. Stał się środkiem wyrazu niemal wszystkiego. Spowszedniał i stracił przebicie sytuacyjne"85.

Rok później $z$ dumą napisała o koncercie galowym $z$ okazji 10-lecia istnienia chóru Ave Verdum w teatrze Ashcroft w Fairfield Halls w Croydon: „Że im się chce poświęcać godziny po pracy, wolne chwile, żeby śpiewać. I polskość wyśpiewywać na obcej ziemi. I w tym śpiewaniu podsycać żar swojej polskości. Bo się w nich ta polskość pali. Nie zgaszona dorastaniem w obcości. Nie poszarzała od kompleksów ani poczucia kulturowej niższości. Ani niedocenienia naszej heroicznej przeszłości”" Darowała im „prowincjonalny obyczaj witania na sali burmistrzów, wójtów i parafialnych działaczy”.

Bez zazwyczaj używanego żądła sarkazmu wypowiadała się o udanym spektaklu pt. Dobry wieczór, Marysiu, wyreżyserowanym przez Helenę Kaut-Howson, opartym na autobiografii, tekstach i muzyce Marysi Drue, żydowskiej dziewczyny $z$ inteligenckiej rodziny z Krakowa, czujacej się Polka, wychowanej w polskiej szkole katolickiej, złapanej w sidła wojny ${ }^{87}$. Dziennikarka była bardzo wzruszona tym obrazem życia na krawędzi zagłady, na progu krakowskiego getta, życia ocalonego dzięki hartowi ducha i pomocy uzyskanej od katolickiego księdza i austriackich gospodarzy (bauerów).

Cywińska zawsze $z$ uznaniem i wielokrotnie odnosiła się do dokonań Sceny Poetyckiej pod egidą Związku Pisarzy Polskich na Obczyźnie,

82 Eadem, „Wieczerza literacka”, Nowy Czas, nr 15 (27), 2007, 10.

83 Eadem, „Trzy po trzy”, Nowy Czas, nr 41 (53), 2007, 8.

84 Eadem, „Nóż w brzuch”, Nowy Czas, nr 42 (54), 2007, 14.

85 Ibidem.

86 Eadem, „Do siego i owego”, Nowy Czas, nr 10 (126), 2009, 12.

87 Eadem, „Oklaski bez mlaskania”, Nowy Czas, nr 5 (141), 2010, 10. 
której występy w POSK-u nazywała „biesiadą dobrze dobranego towarzystwa, rozkochanego w poezji”"8. Zastanawiała się, „ileż to godzin $z$ dala od domowego łona, telewizora i kanapy poświęcają ci szaleńcy na mocowanie się ze słowem. Tylko po to, żeby gościć na poetyckich biesiadach gości takich jak ja. Spragnionych jej smaku"89. Spośród wielu spotkań wspominała wieczór, kiedy cieszyła się z obcowania $z$ balladami, wierszami i Teatrzykiem Zielona Gęś Konstantego Ildefonsa Gałczyńskiego w reżyserii Heleny Kaut-Howson. Przy okazji odniosła się do kampanii wyborczej w Polsce, gdzie trwała debata na temat krzewienia kultury:

Od tego krzewienia aż trzewia bolą. Tu, w Londynie, wieczory poetyckie nie organizuje się w celu krzewienia czegokolwiek, ale dla radości obcowania $z$ polska poezja. ... Wizje poetyckie sa znacznie bardziej porywające niż wizje polityczne. Prawie tak samo mało realne. Te mdłe koszałki-opałki i krasomówcze absurdy mało pocieszne, te zapowiedzi bez ślubu potem, i te ślubowania bez wiary. Wyborcza fantasmagoria i fatamorgana to temat do Teatrzyku Zielona Gęs ${ }^{90}$.

W 2009 r. śmierć w Warszawie dawnego kolegi dziennikarza z Sekcji Polskiej BBC, Macieja Rybińskiego, publicysty, komentatora politycznego, ekonomicznego i społecznego, satyryka, scenarzysty, pisarza, była impulsem do przypomnienia znakomitych felietonistów, którzy byli „echem i odbiciem” polskiej emigracyjnej codzienności ${ }^{91}$. Mistrzami syntezy i dowcipu, kulturowymi erudytami, według niej, byli: Juliusz Sakowski, Stefania Kossowska, Karol Zbyszewski, Zygmunt Nowakowski, Antoni Słonimski. Rybiński zaś - znawca historii i literatury. „A do tego wykrywaczem i wyśmiewaczem nonsensów, blag, nudziarstw i pustosłowia. [...] W zalewie nadętych i przemądrzałych artykułów, wypowiedzi, grafomaństwa i powszechnej frazeologii był niczym latarnik. Ratował nasze piśmiennictwo od zatonięcia w mętnej wodzie patosu"92.

Skreśliła także kilka słów o zmarłym przedwcześnie w Warszawie działaczu „Solidarności”, dowcipnym felietoniście Piotrze Zakrzewskim (1953-2009), który pod pseudonimem Podziomek pisał

88 Eadem, „Fantasmagoria i fatamorgana”, Nowy Czas, nr 15 (172), 2011, 12; eadem, „Powody do zaangażowania”, Nowy Czas, nr 5 (191), 2013, 10.

89 Eadem, „Fantasmagoria i fatamorgana”, Nowy Czas, nr 15 (172), 2011, 12.

90 Ibidem.

91 Eadem, „Pisał, bo był...”, Nowy Czas, nr 17 (133), 2009, 10.

92 Ibidem. 
w „Tygodniu Polskim” - sobotnim dodatku londyńskiego „Dziennika Polskiego i Dziennika Żołnierza"93. Zganiła redakcję dziennika za brak słowa komentarza na ten temat, „bez wyrazów żalu, że odszedł, bez nekrologu"94.

$Z$ wielkim szacunkiem napisała wspomnienie o premier Wielkiej Brytanii w latach 1979-1990, Margaret Thatcher, która zmarła w Londynie 8 kwietnia 2013 r.: „Była osobowością wyjatkowa. $Z$ tą swoją stanowczością, nieugiętością, determinacja graniczaca $z$ uporem i niezłomna wiarą w słuszność swoich poglądów i decyzji. I $z$ tą niespożytą energia. ... Noszę ją w swoim sercu"95.

Nie mogła nie odnieść się do kwestii brexitu ${ }^{96}$, który nazwała „kuwetą multi-kulti”97, który „zdarł kurtynę hipokryzji”98. Bez złudzeń napisała, że „W dniu referendum poszła spać w jej drugiej ojczyźnie. Po referendum obudziła się na obcej ziemi. ... Wyszło szydło $z$ worka. Podskórna brytyjska ksenofobia. Nieprzykrywana dobrymi manierami i nakazem politycznej poprawności. ... Obyczajność z dnia na dzień się zmieniła w wybuchy chamstwa”99. Stwierdziła, że „Idzie niepewność, ... czeka nas pieskie życie po Brexicie"100.

W felietonowych błyskotliwych i poczytnych miniaturach kondensuje aktualne wydarzenia, przenosi do historii epizody biograficzne postaci, intelektualnych środowisk, wykłada rozmaitość i rozwój własnych poszukiwań, refleksje o życiu. I poczucia humoru, często sarkastycznego, zawsze wykwintnie dystansującego prezentowaną rzeczywistość.

Czytelnicy lubią ją za wolność myśli, niezależność sądu, jednak bez złudzeń wobec współczesnego świata. Cenią za to, że pisze smacznie, że „w jej naturze leży szczypanie” ${ }^{101}$. Ma dar wynajdowania tego, co w otaczajacej rzeczywistości najważniejsze. Dzięki doświadczeniu i instynktowi dziennikarskiemu widzi rzeczy szerzej. Ma rzadką umiejętność dogłębnego

\footnotetext{
93 Eadem, „Malkontenctwo”, Nowy Czas, nr 18 (134), 2009, 10.

94 Ibidem.

95 Eadem, „You turn if you want to”, Nowy Czas, nr 4 (190), 2013, 10.

96 Eadem, „Fakty czy mity?”, Nowy Czas, nr 4 (221), 2016, 15.

97 Eadem, „Kuweta muti-kulti”, Nowy Czas, nr September/222, 2016, 15.

98 Eadem, „Karuzela z sympatiami”, Nowy Czas, nr January/226, 2017, 11.

99 Eadem, „Kuweta muti-kulti”, Nowy Czas, nr September/222, 2016, 15.

${ }^{100}$ Eadem, „Czy zejdziemy na psy?”, Nowy Czas, nr March/228, 2017, 13.

${ }^{101}$ Eadem, „Oklaski bez mlaskania”, Nowy Czas, nr 5 (141), 2010, 10.
} 
komentowania tego, co się dzieje. Zawsze dowcipna, ironiczna, a jednocześnie wrażliwa, $z$ drogowskazem dla emigrantów: „dajcie szansę optymizmowi"102.

\section{Bibliografia}

\section{Źródła}

Cywińska, Krystyna. „A w mediach gadu gadu...," Nowy Czas, nr 7-8 (193194), 2013, 10.

Cywińska, Krystyna. „Bajeczko o...”, Nowy Czas, nr 21 (33), 2007, 8.

Cywińska, Krystyna. „Bum, bum”, Nowy Czas, nr 31 (42), 2007, 8.

Cywińska, Krystyna. „Brytyjskość”, Nowy Czas, nr 47 (59), 2007, 12.

Cywińska, Krystyna. „Ciemna masa”, Nowy Czas, nr 8 (144), 2010, 14.

Cywińska, Krystyna. „Co donosi echo?”, Nowy Czas, nr 23 (35), 2007, 8.

Cywińska, Krystyna. „Credo”, Nowy Czas, nr 51-52 (63-64), 2007, 14.

Cywińska, Krystyna. „Czwarty świat”, Nowy Czas, nr 34 (99), 2008, 12.

Cywińska, Krystyna. „Czwarty świat”, Nowy Czas, nr 8 (165), 2011, 12.

Cywińska, Krystyna. „Czy podzielimy los starożytnych Rzymian?”, Nowy Czas, nr 9 (218), 2015, 13.

Cywińska, Krystyna. „Czy zejdziemy na psy?”, Nowy Czas, nr March/228, 2017, 13.

Cywińska, Krystyna. „Demony demokracji”, Nowy Czas, nr 4 (140), 2010, 10. Cywińska, Krystyna. „Diabolizm”, Nowy Czas, nr 40 (52), 2007, 8.

Cywińska, Krystyna „Do Siego itd.”, Nowy Czas, nr 1 (137), 2010, 10.

Cywińska, Krystyna. „Do siego i owego”, Nowy Czas, nr 1 (65-66), 2008, 12.

Cywińska, Krystyna. „Do siego i owego”, Nowy Czas, nr 10 (126), 2009, 12.

Cywińska, Krystyna. „Do urn”, Nowy Czas, nr 42 (54), 2007, 8.

Cywińska, Krystyna. „Donosy o donosach”, Nowy Czas, nr 31 (96), 2008, 12.

Cywińska, Krystyna. „Donoszę, że...”, Nowy Czas, nr 18 (30), 2007, 12.

Cywińska, Krystyna. „Dramat czy farsa?”, Nowy Czas, nr 13 (170), 2011, 12.

Cywińska, Krystyna. „Dwa łona”, Nowy Czas, nr 14 (130), 2009, 12.

Cywińska, Krystyna. „Dwie ojczyzny”, Nowy Czas, nr 2 (179), 2012, 10.

$\overline{102}$ Eadem, „Do siego i owego”, Nowy Czas, nr 1 (65-66), 2008, 12. 
Cywińska, Krystyna. „Dziennikarskie hieny”, Nowy Czas, nr 19 (176), 2011, 10.

Cywińska, Krystyna. „Dziewczyny w okryjbidkach”, Nowy Czas, nr 13 (148), 2010, 10.

Cywińska, Krystyna. „Fakty czy mity?”, Nowy Czas, nr 4 (221), 2016, 15. Cywińska, Krystyna. „Fama głosi...”, Nowy Czas, nr 19 (155), 2010, 10.

Cywińska, Krystyna. „Fantasmagoria i fatamorgana”, Nowy Czas, nr 15 (172), 2011, 12.

Cywińska, Krystyna. „Farsa w POSK-u”, Nowy Czas, nr 49 (61), 2007, 12.

Cywińska, Krystyna. „Galopujacy Gallup”, Nowy Czas, nr 37 (49), 2007, 8. Cywińska, Krystyna. „Inkwizycja”, Nowy Czas, nr 16 (28), 2007, 10.

Cywińska, Krystyna. „Inkwizycja”, Nowy Czas, nr 22 (87), 2008, 12.

Cywińska, Krystyna. „Jak równy z równym”, Nowy Czas, nr 1 (187), 2013, 10. Cywińska, Krystyna. „Język pod latarnia”, Nowy Czas, nr 26 (38), 2007, 8. Cywińska, Krystyna. „Karłowatość”, Nowy Czas, nr 12 (24), 2007, 10. Cywińska, Krystyna. „Karuzela z sympatiami”, Nowy Czas, nr January/226, 2017, 11.

Cywińska, Krystyna. „Kociokwik”, Nowy Czas, nr 9 (145), 2010, 10.

Cywińska, Krystyna. „Konkubinat”, Nowy Czas, nr 29 (41), 2007, 8.

Cywińska, Krystyna. „Koszałki-opałki”, Nowy Czas, nr 18 (154), 2010, 10.

Cywińska, Krystyna. „Krótka piłka”, Nowy Czas, nr 20 (85), 2008, 14.

Cywińska, Krystyna. „Krytykując, czyli plując, trując i szkalując”, Nowy Czas, nr 2 (212), 2015, 15.

Cywińska, Krystyna. „Ku przestrodze”, Nowy Czas, nr 4 (120), 2009, 14.

Cywińska, Krystyna. „Kuweta muti-kulti”, Nowy Czas, nr September/222, 2016, 15.

Cywińska, Krystyna. „Majowe refleksje”, Nowy Czas, nr 5 (203), 2014, 10. Cywińska, Krystyna. „Malkontenctwo”, Nowy Czas, nr 18 (134), 2009, 10. Cywińska, Krystyna. „Miasto nieposkromione”, Nowy Czas, nr 30 (95), 2008, 12.

Cywińska, Krystyna. „Miasto nieposkromione”, Nowy Czas, nr 7 (205), 2014, 16.

Cywińska, Krystyna. „Minusowy plus”, Nowy Czas, nr 25 (90), 2007, 12.

Cywińska, Krystyna. „Mój stan zawieszenia”, Nowy Czas, nr 3 (189), 2013, 10. Cywińska, Krystyna. „Narkotyk polityczny”, Nowy Czas, nr 36 (101), 2008, 14. 
Cywińska, Krystyna. „Niesmak i smak nienawiści”, Nowy Czas, nr 8 (185), 2012, 10.

Cywińska, Krystyna. „Niezgodna zgodna”, Nowy Czas, nr 43 (108), 2008, 12. Cywińska, Krystyna. „No i super”, Nowy Czas, nr May/June/230-231, 2017, 13.

Cywińska, Krystyna. „Nowe okulary kupię”, Nowy Czas, nr 1 (199), 2014, 10. Cywińska, Krystyna. „Nóż w brzuch”, Nowy Czas, nr 42 (54), 2007, 14.

Cywińska, Krystyna. „Odwieczna paplanina”, Nowy Czas, nr 19 (135), 2009, 14.

Cywińska, Krystyna. „Oklaski bez mlaskania”, Nowy Czas, nr 5 (141), 2010, 10.

Cywińska, Krystyna. „Oskarżenia czy zarzuty?”, Nowy Czas, nr 3 (68), 2008, 12.

Cywińska, Krystyna. „Oskarżenia czy zarzuty?”, Nowy Czas, nr 9 (125), 2009, 10.

Cywińska, Krystyna. „Piątka z plusem”, Nowy Czas, nr 15 (172), 2011, 17. Cywińska, Krystyna. „Patriotyczna fanfaronada $z$ domieszką fantazji”, Nowy Czas, nr 3 (213), 2015, 11.

Cywińska, Krystyna. „Partykularz”, Nowy Czas, nr 5 (70), 2008, 12.

Cywińska, Krystyna. „Peregrynacja”, Nowy Czas, nr 11 (23), 2007, 10.

Cywińska, Krystyna. „Pisał, bo był...”, Nowy Czas, nr 17 (133), 2009, 10.

Cywińska, Krystyna. Płonne nadzieje”, Nowy Czas, nr 7 (185), 2012, 12.

Cywińska, Krystyna. „Pokłonu nie złożono”, Nowy Czas, nr 6 (183), 2012, 10.

Cywińska, Krystyna. „Polały się łzy”, Nowy Czas, nr 7 (143), 2010, 14.

Cywińska, Krystyna. „Politycy i psychole”, Nowy Czas, nr 16 (152), 2010, 12.

Cywińska, Krystyna. „Polowanie z nagonka”, Nowy Czas, nr 11 (147), 2010, 12.

Cywińska, Krystyna. „Polski patriotyzm”, Nowy Czas, nr 28 (93), 2008, 12. Cywińska, Krystyna. „Polskie hobby”, Nowy Czas, nr 2 (67), 2008, 12.

Cywińska, Krystyna. „Polsko-szkockie krewkie życie”, Nowy Czas, nr 8 (206), 2014, 1.

Cywińska, Krystyna. „Pong-mowa”, Nowy Czas, nr 27 (92), 2008, 12

Cywińska, Krystyna. „Posłannictwo”, Nowy Czas, nr 10 (22), 2007, 10.

Cywińska, Krystyna. „Powody do zaangażowania”, Nowy Czas, nr 5 (191), 2013, 10. 
Cywińska, Krystyna. „Prawda czy półprawdy?”, Nowy Czas, nr 3 (160), 2011, 10.

Cywińska, Krystyna. „Przetrwamy”, Nowy Czas, nr 27 (39), 2007, 8.

Cywińska, Krystyna. „Rozliczanie”, Nowy Czas, nr 13 (25), 2007, 10.

Cywińska, Krystyna. „Sentimental Journey”, Nowy Czas, nr 14 (171), 2011, 10.

Cywińska, Krystyna. „Shibboleth”, Nowy Czas, nr 17 (29), 2007, 10.

Cywińska, Krystyna. „Skrzek”, Nowy Czas, nr 20 (32), 2007, 12.

Cywińska, Krystyna. „Stereotyp w błocie”, Nowy Czas, nr 44 (109), 2008, 14.

Cywińska, Krystyna. „Strzela baba z łuku”, Nowy Czas, nr 6 (163), 2011, 10.

Cywińska, Krystyna. „Święte krowy”, Nowy Czas, nr 10 (146), 2010, 14.

Cywińska, Krystyna. „Świątecznie i nieświątecznie”, Nowy Czas, nr 9 (186), 2012, 12.

Cywińska, Krystyna. „Takie życie...”, Nowy Czas, nr 11 (168), 2011, 10.

Cywińska, Krystyna. „Tere-fere kuku”, Nowy Czas, nr 19 (31), 2007, 10.

Cywińska, Krystyna. „Trefnie czy trafnie?”, Nowy Czas, nr 10 (167), 2011, 10.

Cywińska, Krystyna. „Trochę nostalgii w Nowy Rok”, Nowy Czas, nr 1 (219), 2016, 15.

Cywińska, Krystyna. „Trzy po trzy”, Nowy Czas, nr 41 (53), 2007, 8.

Cywińska, Krystyna. „Tu mówił Londyn”, Nowy Czas, nr 15 (131), 2009, 14.

Cywińska, Krystyna. „Upupi i obłupi?”, Nowy Czas, nr 8 (72), 2008, 12.

Cywińska, Krystyna. „W realu”, Nowy Czas, nr 3 (139), 2010, 10.

Cywińska, Krystyna. „Wet za wet”, Nowy Czas, nr 21 (86), 2008, 12.

Cywińska, Krystyna. „Wieczerza literacka”, Nowy Czas, nr 15 (27), 2007, 10.

Cywińska, Krystyna. „Wieczerza literacka”, Nowy Czas, nr 37 (102), 2007, 14.

Cywińska, Krystyna. „Wielbiciele mitów”, Nowy Czas, nr 9 (195), 2013, 10.

Cywińska, Krystyna. „Wielbiciele mitów”, Nowy Czas, nr 11 (197), 2013, 12.

Cywińska, Krystyna. „Wirtualne zmory”, Nowy Czas, nr 7 (164), 2011, 10.

Cywińska, Krystyna. „Wkurzenie”, Nowy Czas, nr 34 (46), 2007, 8.

Cywińska, Krystyna. „Wojenna glątwa”, Nowy Czas, nr 3 (201), 2014, 12.

Cywińska, Krystyna. „Worek Judaszy”, Nowy Czas, nr 7 (123), 2009, 10.

Cywińska, Krystyna. „Wszystkie nasze dzienne sprawy”, Nowy Czas, nr April/229, 2017, 11.

Cywińska, Krystyna. „You turn if you want to”, Nowy Czas, nr 4 (190), 2013, 10.

Cywińska, Krystyna. „Zaduszki”, Nowy Czas, nr 44 (56), 2007, 8. 
Cywińska, Krystyna. „Zaleja nas, czy nie zaleją?, Nowy Czas, nr 7 (216), 2015, 17.

Cywińska, Krystyna. „Zenk you, że mnie czytacie”, Nowy Czas, nr October/223, 2016, 13.

Cywińska, Krystyna. „Złota starość, Nowy Czas, nr 12 (128), 2009, 10.

Cywińska, Krystyna. „Życie w rozkroku”, Nowy Czas, nr 36 (48), 2007, 8.

Gazdziński, R.A. „Londyńskie wspomnienia powstańców [1]”, Nowy Czas, nr 7 (205), 2014, 17.

Małkiewicz, Grzegorz. „Felietonistka z pazurem”, Nowy Czas, nr October/ 223, 2016, 15.

Nowy Czas, nr 10 (22), 2007, 1.

\section{Opracowania}

Bzowska-Budd, Katarzyna (red.), Dopóki jest „Dziennik”-jestem..., (Londyn: Polska Fundacja Kulturalna, 2000).

Chwastyk-Kowalczyk, Jolanta. „Antoni Bogusławski - the forgotten journalist, poet, writer, translator, author of children literature, literary critic, oficer", Rocznik Historii Prasy Polskiej, t. 21, z. 1(19), 2018, 5-21.

Chwastyk-Kowalczyk, Jolanta. „Czy niezależne pisma emigracyjne moga zmienić rzeczywistość polskiej diaspory?”, Politeja, nr 25, 2014, 229-246.

Chwastyk-Kowalczyk, Jolanta. „Maria Danilewicz-Zielińska i Stefania Kossowska - niezapomniane postacie kultury polskiej”, w: Urszula Kozłowska, Tomasz Sikorski, Adam Wator (red.), Obywatelki na obcasach. Kobiety $w$ życiu publicznym (XIX i XX w.) t. 1, (Radzymin-Warszawa: Wydawnictwo von borowiecky, 2016), 227-244.

Chwastyk-Kowalczyk, Jolanta. "Nowy Czas. New Time» - czasopismo polskiej inteligencji w Wielkiej Brytanii (2006-2014)", Rocznik Historii Prasy Polskiej, z. 2 (38), 2015, 50-81.

Chwastyk-Kowalczyk, Jolanta. „Nowy Czas. New Time». Intrygujace czasopismo polskiej inteligencji w Wielkiej Brytanii (2006-2013)”, Respectus Philologicus, nr 27 (32), 2015, 93-103.

Chwastyk-Kowalczyk, Jolanta. „Recenzje książek opublikowane na łamach "Nowego Czasu» w Wielkiej Brytanii w XXI wieku”, w: Arkadiusz Pulikowski (red.), Kultura ksiażki i informacji, (Katowice: Wydawnictwo Uniwersytetu Ślaskiego, 2017), 71-89. 
Chwastyk-Kowalczyk, Jolanta. „Sieciowa postać polskich czasopism emigracyjnych w Wielkiej Brytanii po 2004 roku", Zeszyty Prasoznawcze, t. 59, nr 2 (226), 2016, 451-463.

Chwastyk-Kowalczyk, Jolanta. „The London Intercultural Integration Initiatives of the 'Nowy Czas. New Time' between 2009-2013", Media $i$ Spoleczeństwo, nr 8, 2017, 171-184.

Chwastyk-Kowalczyk, Jolanta. Londyński „Dziennik Polski i Dziennik Żolnierza” 1944-1989. Gazeta codzienna jako środek przekazu komunikatów kulturowych, (Kielce: Wydawnictwo Uniwersytetu Humanistyczno-Przyrodniczego Jana Kochanowskiego, 2008).

Chwastyk-Kowalczyk, Jolanta. Londyński „Dziennik Polski” 1940-1943, (Kielce: Wydawnictwo Akademii Świętokrzyskiej, 2005).

Chwastyk-Kowalczyk, Jolanta. Sposoby e-komunikowania społeczności polskiej na Wyspach Brytyjskich $i$ w Irlandii jako przedtużenie krajowego systemu medialnego, w: Radosław Sierocki, Marek Sokołowski (red.), Konkurencyjny rynek medialny. Telewizja wobec nowych mediów, (Toruń: Wydawnictwo Adam Marszałek, 2011), 80-96.

Leonowicz-Bukała, Ilona. Polskie media $w$ Wielkiej Brytanii na poczatku XXI wieku, (Warszawa-Rzeszów: WSIiZ - ASPRA-JR, 2015).

Taborska, Halina. Lewandowska-Tarasiuk, Ewa (red.), The Hanna \& Zdzisław Broncel Charitable Trust-fundatorzy, powiernicy beneficjenci, (Londyn: PUNO Press, 2016).

\section{Publikacje internetowe}

Powstańcze biogramy: Krystyna Wyderko. [online] [dostęp: 22.08.2017]. Dostępny w World Wide Web: http://www.1944.pl/powstancze-biogramy/ krystyna-wyderko,50448.html. 